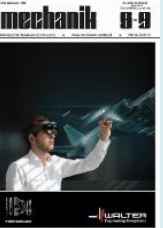

\title{
Analysis of selected surface roughness parameters the AW 6082 T6 aluminum alloy after turning process
}

\section{Analiza wybranych parametrów chropowatości powierzchni po procesie toczenia stopu aluminium AW 6082 T6}

\section{MARIUSZ KŁONICA *}

The paper presents selected research results concerning the surface roughness analysis of $2 \mathrm{D}$ and $3 \mathrm{D}$ after the turning process AW 6082 T6 aluminum alloy. The conical and spherical surfaces were analyzed. Samples made of aluminum alloy were made on a DMG MORI CTX450 numerically controlled lathe equipped with the Sinumerik 840D control system. The Hommel-Etamic T8000 RC-12-40 measuring device with a measuring radius of $2 \mu \mathrm{m}$ was used to measure the selected surface roughness parameters. The Keyence VHX-5000 microscope was also used in the study to visualize the resulting surfaces.

KEYWORDS: AW 6082 T6 aluminum alloy, surface roughness parameters, surface layer

In selecting the technological parameters of turning machining, it is important to choose the feed speed correctly because it affects the time of the machining. This parameter is directly influenced by the obtained surface roughness parameters, which is important especially when the turning is the final machining $[2-4,6,7]$. The technologist, striving to obtain satisfactory machining time and the required surface quality, most often has to decide whether to increase the cutting speed at a low depth or to increase the depth of cut while maintaining the cutting speed at a reduced level $[8,9]$. Together with the improvement of machining efficiency and the development of highperformance cutting methods, the requirements for modern cutting tools are increasing. The basic determinant of the suitability of the machining tool is to ensure an adequate quality of the surface layer after processing.

This article analyzes the influence of feed speed on the obtained values of selected surface roughness parameters after the AW 6082 T6 aluminum alloy turning process - a material important for the industrial sector.

\section{Research methodology}

The tests used semi-finished products made of aluminum alloy AW 6082 T6 in the shape of rollers with a diameter of $80 \mathrm{~mm}$. The samples were made in two variants: with conical surfaces and with spherical surfaces.

The dimensions of conical samples are: the height of the truncated cone $L=30 \mathrm{~mm}$, the diameters of the cone bases $D_{1}=30 \mathrm{~mm}$ and $D_{2}=50 \mathrm{~mm}$.

Samples with spherical geometry had a radius of $R=30$ $\mathrm{mm}$. Their dimensions are shown in fig. 1 .

\footnotetext{
* Dr inż. Mariusz Kłonica (m.klonica@pollub.pl) - Katedra Podstaw Inży-
} nierii Produkcji, Wydział Mechaniczny Politechniki Lubelskiej

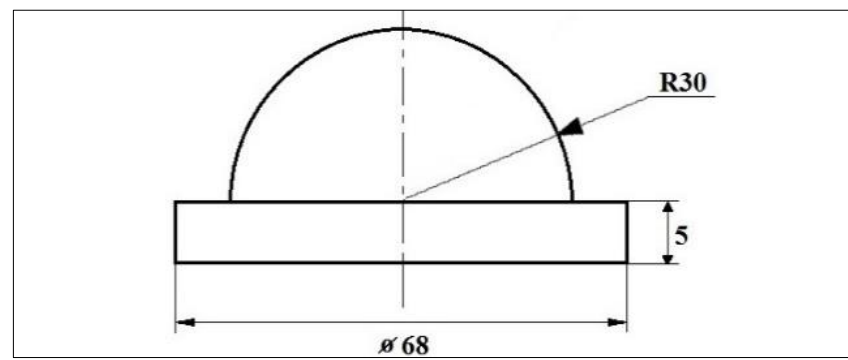

Fig. 1. Dimensions of spherical samples made of AW 6082 T6 aluminum alloy

The turning process was carried out using a cooling liquid.

In tab. I, the technology of sample preparation is presented. During the research a Sandvik folding knife was used (holder DCLNL2525M and plate CNMG120408PM4225). The machining process was carried out on a numerically controlled CTX450 lathe from DMG. Selected surface roughness parameters were measured using a Hommel-Etamic T8000 RC-12-40 device for measuring contour, roughness and topography, with a measuring tip of $2 \mu \mathrm{m}$ radius. The measurement of $2 \mathrm{D}$ parameters was carried out perpendicular to the traces created after machining. For each of the variants, a minimum of 10 repetitions were performed.

3D topography was made on the surface $1.6 \times 1.6 \mathrm{~mm}$ with 160 rows. TURBO WAVE software was used for analysis. The elementary segment was selected on the basis of literature [1, 5, 10, 11]. The Keyence VHX-5000 microscope was used to visualize the surface after treatment.

TABLE I. Technology of sample preparation from aluminum alloy AW 6082 T6

\begin{tabular}{|c|c|c|}
\hline \multicolumn{2}{|c|}{ Machining parameters } \\
\hline$f, \mathrm{~mm} / \mathrm{obr}$ & $v_{\mathrm{c}}, \mathrm{m} / \mathrm{min}$ & $a_{\mathrm{p}}, \mathrm{mm}$ \\
\hline 0.15 & & \\
\hline 0.20 & \multirow{3}{*}{300} & \multirow{2}{*}{1.5} \\
\hline 0.25 & & \\
\hline 0.30 & & \\
\hline 0.35 & & \\
\hline
\end{tabular}

\section{Results}

The analysis of selected surface roughness parameters $2 \mathrm{D}$ and $3 \mathrm{D}$ after the aluminum alloy turning process. From the group of $2 \mathrm{D}$ parameters the parameters $R a$ (arithmetic mean of ordinates roughness) and $R z$ (maximum height 
profile roughness) were analyzed, while from the group 3D$\mathrm{Sa}$ parameters (arithmetic mean deviation of the surface unevenness from the reference plane), $S z$ (maximum height of the 3D profile), St (deviation of the main texture direction of the surface from the axis of $90^{\circ}$, perpendicular to the direction of data collection), and $S k u$ (the coefficient of concentration of the topography height distribution (ordinates)).

Tab. II presents isometric views of conical surfaces after the aluminum alloy turning process and obtained values of $3 \mathrm{D}$ roughness parameters.

Based on the tests carried out and the analysis of the results, the selected 3D roughness parameters $(S a, S z, S t)$ were found along with the increase of the feed rate in the whole range of feed speed values used. The parameter of the surface roughness of 3D Sku in all cases remained at the same level.

Tab. III presents the isometric views of spherical surfaces after the aluminum alloy turning process and obtained values of 3D roughness parameters.

TABLE II. Isometric views of conical surfaces and 3D surface roughness parameters

\begin{tabular}{|c|c|c|c|}
\hline $\begin{array}{c}\text { Feedrate, } \\
\mathrm{mm} / \mathrm{rev}\end{array}$ & Isometric image & \multicolumn{2}{|c|}{ 3D parameter } \\
\hline \multirow{4}{*}{0.15} & & $S a, \mu \mathrm{m}$ & 1.3 \\
\hline & & $S z, \mu \mathrm{m}$ & 10.6 \\
\hline & & $S t, \mu \mathrm{m}$ & 10.6 \\
\hline & $e^{x}$ & Sku & 2.38 \\
\hline \multirow{4}{*}{0.20} & & $S a, \mu \mathrm{m}$ & 1.96 \\
\hline & & $S z, \mu \mathrm{m}$ & 13.9 \\
\hline & & $S t, \mu \mathrm{m}$ & 13.9 \\
\hline & $2 x^{x}$ & Sku & 2.41 \\
\hline \multirow{4}{*}{0.25} & & $S a, \mu \mathrm{m}$ & 2.87 \\
\hline & & $S z, \mu \mathrm{m}$ & 18.2 \\
\hline & & $S t, \mu \mathrm{m}$ & 18.2 \\
\hline & $e^{x}$ & Sku & 2.12 \\
\hline \multirow{4}{*}{0.30} & & $S a, \mu \mathrm{m}$ & 4.10 \\
\hline & & $S z, \mu \mathrm{m}$ & 25.1 \\
\hline & & $S t, \mu \mathrm{m}$ & 25.1 \\
\hline & $\psi^{x}$ & Sku & 2.24 \\
\hline \multirow{4}{*}{0.35} & & $S a, \mu \mathrm{m}$ & 5.41 \\
\hline & & $S z, \mu \mathrm{m}$ & 25.2 \\
\hline & & $S t, \mu \mathrm{m}$ & 25.2 \\
\hline & $z^{x}$ & Sku & 1.90 \\
\hline
\end{tabular}

TABLE III. Isometric views of spherical surfaces and 3D surface roughness parameters

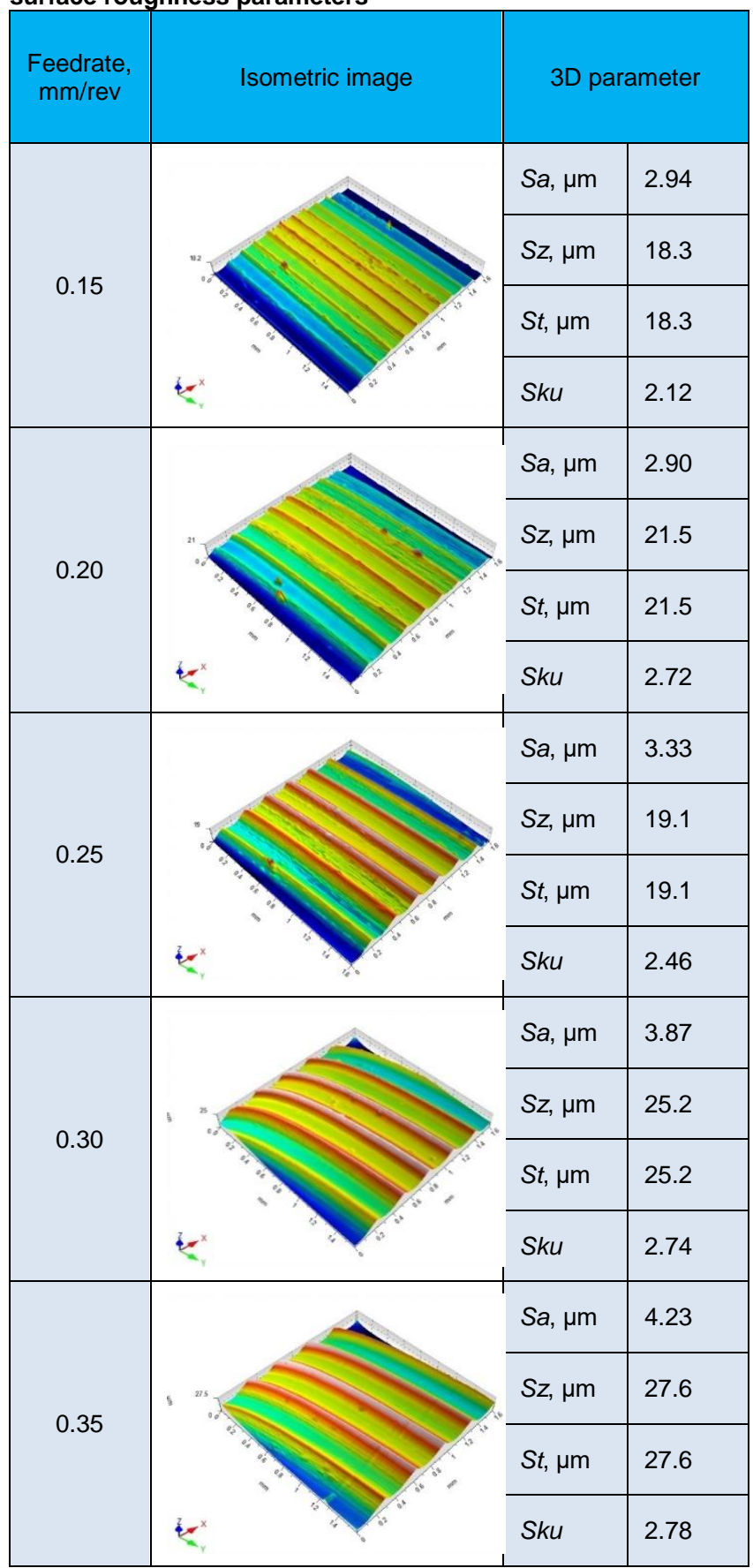

Similarly as in the case of conical surfaces, also for the spherical surfaces an increase in selected surface roughness parameters was observed along with the increase of the feed speed. It was also noted that with the same feed rate values, Sa, Sz and St parameters are higher for spherical surfaces than for conical surfaces.

The surface topography maps - both conical and spherical - show the traces of surface formation typical of machining, constituting a kinematic-geometric representation of the tool.

Tab. IV presents the photographs of conical and spherical surfaces obtained after the treatment of the aluminum alloy AW 6082 T6, with a magnification of $\times 300$. By analyzing the posted photographs of the surface after the rolling process with different feed speeds, it can be seen that as the feed rate increases, the surface furrows become deeper and deeper. It was found that all surfaces are characterized by parallel traces of the blade. On the surface of the samples, you can also see the loss of material, which is the result of chipping. 
Fig. 2 shows the influence of the feed speed value on the $R a$ parameter value of the conical and spherical surface after the aluminum alloy turning process.

TABLE IV. Photographs of conical and spherical surfaces created after machining of an aluminum alloy
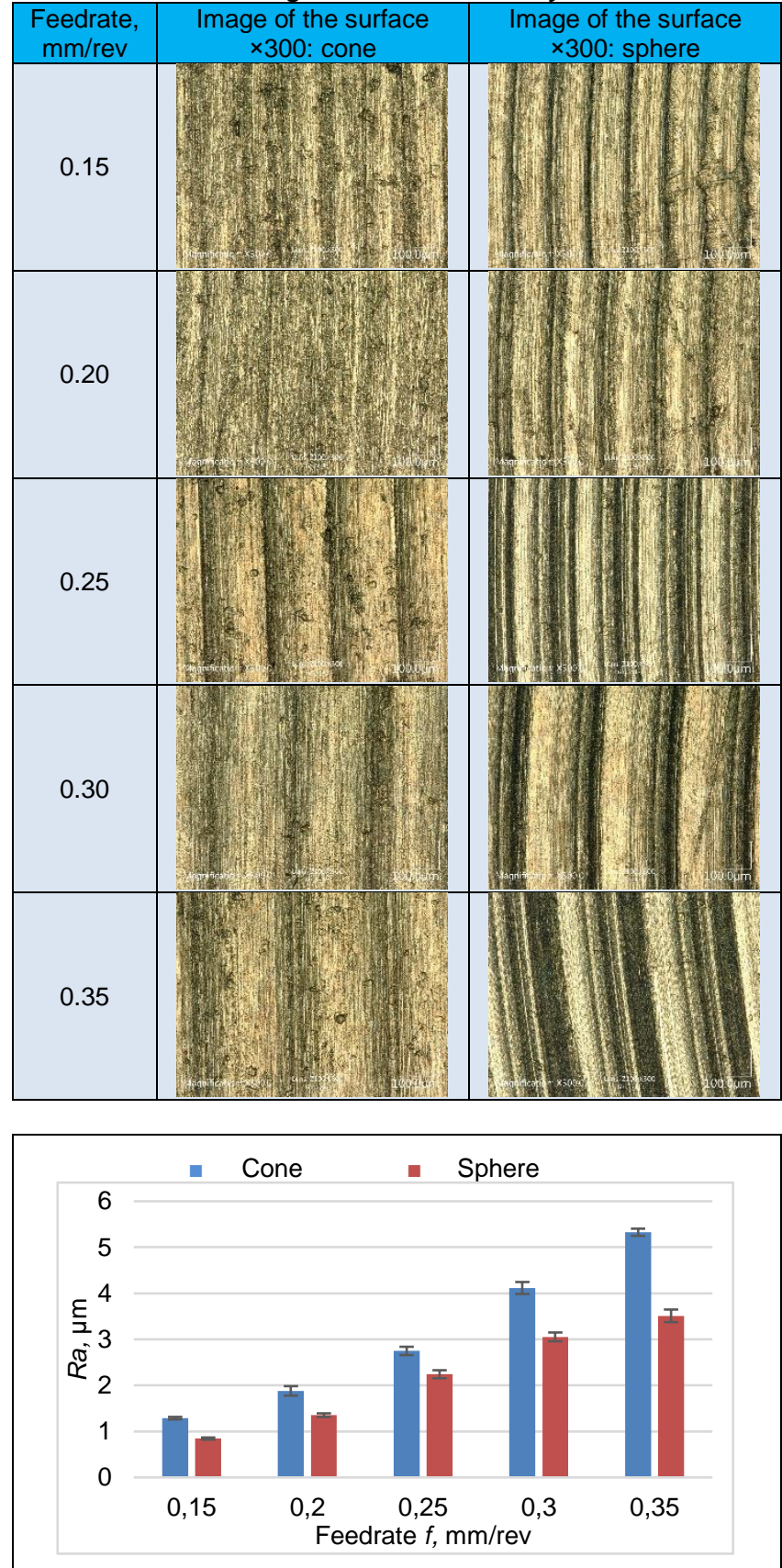

Fig. 2. Influence of feedrate value on the Ra surface roughness parameter value

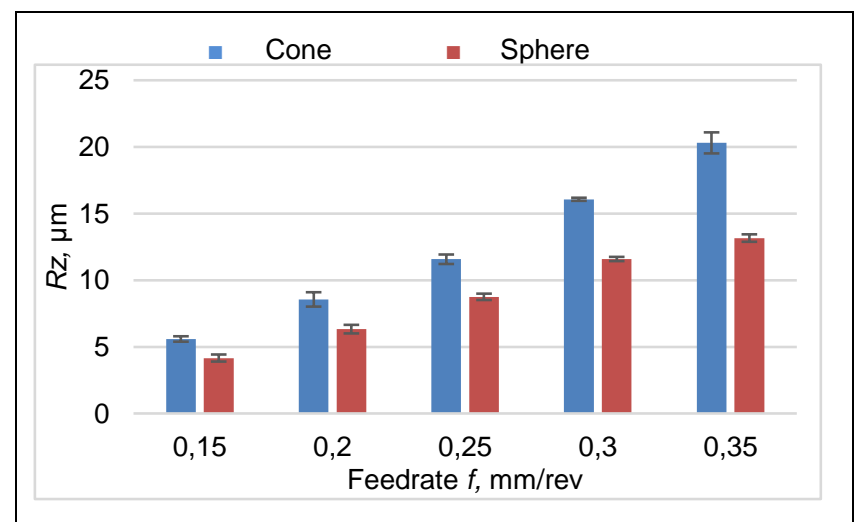

Fig. 3. Influence of the feedrate value on the surface roughness parameter $R z$ parameter
On the basis of the conical and spherical surface tests, the surface roughness parameter $R a$ was increased along with the increase of the feed speed. Noteworthy is the large concentration of results around the average value. For a feed rate of $0.15 \mathrm{~mm} / \mathrm{rev}$, the roughness parameter $R a$ was approx. $1 \mathrm{~mm}$. With the increase of the feed value, the difference between the $R a$ parameter for conical and spherical surfaces is increasing - with a feed rate of 0.35 $\mathrm{mm} / \mathrm{rev}$, it is $35 \%$.

Fig. 3 shows the values of the $R z$ parameter of the 2D surface roughness depending on the value of the feed speed.

For a conical surface, a four-fold increase in the surface roughness parameter $R z$ parameter for a feed rate of 0.35 $\mathrm{mm} / \mathrm{rev}$ was observed in relation to the value of the feed rate of $0.15 \mathrm{~mm} / \mathrm{rev}$.

\section{Conclusions}

On the basis of the analyzes and experimental studies carried out, the following general conclusions were formulated:

- In the whole range of applied feed speed, an increase in surface roughness parameters was observed - both 2D $(R a, R z)$ and 3D (Sa, Sz, St).

- For conical surfaces, a larger spread of the obtained results was observed - standard deviation (fig. 2 and fig. 3 ).

- In surface photographs after the turning process with different feed rates, it can be seen that as the feed rate increases, the surface furrows become deeper. All surfaces are characterized by parallel traces of the tool edge.

\section{REFERENCES}

1. Adamczak S. „Pomiary geometryczne powierzchni. Zarysy ksztaltu, falistość i chropowatość". Warszawa: WNT, 2008.

2. Blicharski M. „Inżynieria powierzchni”. Warszawa: Wydawnictwa Naukowo-Techniczne, 2009.

3. Grzesik W. „Podstawy skrawania materiałów metalowych”. Warszawa: Wydawnictwa Naukowo-Techniczne, 2010.

4. Grzesik W. „Wpływ topografii powierzchni na właściwości eksploatacyjne części maszyn". Mechanik. 8-9 (2015): pp. 587-593.

5. Humienny Z.(red.) „Specyfikacje Geometrii Wyrobów (GPS) wykład dla uczelni technicznych". Warszawa: Oficyna Wydawnicza PW, 2001.

6. Kamieńska-Krzowska B., Kłonica M. „Rola strategii pomiarów topografii powierzchni $w$ ocenie wybranych parametrów chropowatości”. Mechanik. 8-9 (2014): pp. 138-145/595.

7. Kłonica M., Kuczmaszewski J. „Analiza procesu formowania wióra w procesie toczenia stopu aluminium AW7075". Mechanik. 10 (2016): pp. 1382-1383.

8. Kuczmaszewski J., Zaleski K. „Obróbka skrawaniem stopów aluminium i magnezu” Lublin: Politechnika Lubelska, 2015.

9. Olszak W. „Obróbka skrawaniem”. Warszawa: Wydawnictwa Naukowo-Techniczne, 2009.

10.Wieczorowski M., Cellery A., Chajda J. „Przewodnik po pomiarach nierówności powierzchni czyli o chropowatości i nie tylko". Poznań: Politechnika Poznańska, 2006.

11.Wieczorowski M. „Podstawy teoretyczne filtracji morfologiczne w pomiarach chropowatości powierzchni”. Archiwum Technologii Maszyn i Automatyzacji. 4 (2009): pp. 41-49.

Translation of scientific articles, their computer composition and publishing them on the website www.mechanik.media.pl by original articles in Polish is a task financed from the funds of the Ministry of Science and Higher Education designated for dissemination of science.

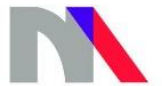

